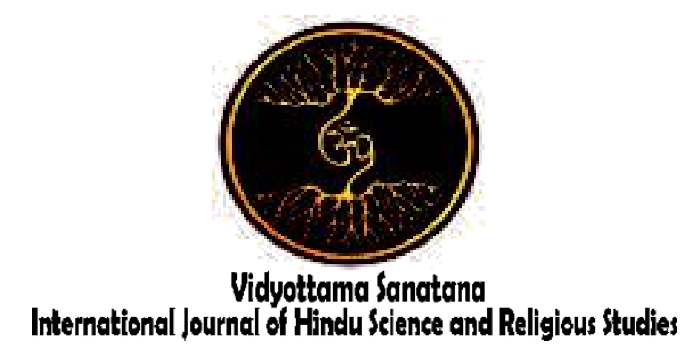

Vol. 4 No. 1 May 2020

\title{
BUILDING THE YOUTHS CHARACTERS THROUGH STRENGTHENING OF HINDU RELIGIOUS EDUCATION
}

\author{
By: \\ I Nyoman Winia ${ }^{1}$, Hari Harsananda ${ }^{2}$, Prasanthy Devi Maheswari ${ }^{3}$, \\ Made G. Juniartha ${ }^{4}$, Kadek Hengki Primayana ${ }^{5}$ \\ ${ }^{1}$ Politeknik Negeri Bali \\ ${ }^{234}$ Universitas Hindu Negeri I Gusti Bagus Sugriwa Denpasar \\ ${ }^{5}$ Sekolah Tinggi Agama Hindu Negeri Mpu Kuturan Singaraja \\ E-mail : ${ }^{1}$ nyomanwinia@pnb.ac.id, ${ }^{2}$ harsananda@ihdn.ac.id, ${ }^{3}$ prasanthy@ihdn.ac.id, \\ 4juniartha@ihdn.ac.id, ${ }^{5}$ hengkiprimayana@gmail.com
}

Received: May 022020

Accepted: May 19, 2020

Published: May 30, 2020

\begin{abstract}
This study aims to find an increase in the role of Hindu religious education in building the humanist and pluralist youth characters. Youth is a transition from childhood to adulthood, wherein the development phase has to undergo various tensions, one of them is emotional tension resulting from relationships. Youth is often not able to overcome the problems associated with emotional control maximally hence they fall into less humanistic and pluralistic relationships or even lead to juvenile delinquency. The low ability of youths in controlling emotions is caused by the lack of religious teachings internalization properly. If religion properly internalized in teenagers, it can foster and shape good emotional control, hence teenage lives will be more directed and all forms of inhumane and pluralist behavior in life between people can be avoided. Hindu religious education has an important role in developing humanist and pluralist youth in multicultural life.
\end{abstract}

Keywords: Hindu Religious Education; Youth; Humanist and Pluralist

\section{INTRODUCTION}

Nowadays, the discourse of increasing the religious education role is strengthening and becoming the focus of attention as a response to various national problems, especially the violence issues in the name of religion and clashes between ethnic groups.
According to Tilaar (1999), this phenomenon is one of the excesses of community conditions that in the social transformation period facing the globalization era. The globalization era itself according to Robertson in Globalization: Social Theory and Global Culture, will generate the global culture 
(which) is encompassing the world at the international level. The condition of global culture has brought positive and negative impacts in Indonesia. The culture of western countries which tend to prioritize rationality, affect eastern countries including Indonesia which still holds the customs and ancestral culture that upholds the values of tradition and religious spirituality.

The fact above is the biggest challenge for the education world these days. The education process as an effort to bequeath the noble values of a nation that aims to produce a superior generation intellectually while maintaining the personality and identity as a nation. Wherever and whenever the education is, it is believed to be a powerful media to shape teenage personalities towards maturity. Tilaar expressed his perspective on the operational understanding of the nature of education as a process of fostering the existence of students who are socialized, cultured in a life order that has local, national, and global dimensions (Tilaar, 2002). Therefore, education can be interpreted as a continuous process, that educating youth is a process that will never be completed. Education does not stop when teens become adults but will continue to develop as long as there is an interaction between humans and the environment, fellow human beings, and their natural environment. Education has a duty to foster the existence of adolescence as an interactive existence, which is not only with fellow humans but also with nature and including with the creator. When the spiritual discourse was at play, the distinction between the materialist worldview and a belief in the transcendent was not very clear, and students expressed both pantheistic and transcendent views, while simultaneously describing themselves as atheists. In line with this are the following excerpts from a group of male students in a conversation with a teacher (Kittelmann Flensner, 2015).

In social and state life, there are various religions and beliefs, where each of the religions or beliefs has a variety of differences, especially related to faith, the way of connecting yourself to God, and ethics. These differences characterize religious life in society. However, certain aspects have similarities, for example concerning humanity. Similarities and differences between religions and belief in God Almighty are reflected in the sociocultural life of Indonesia based on Pancasila with Unity in Diversity. Occasionally, there are frictions, if it does not eliminate like a disease, it can endanger the unity and integrity nation.

Religious education is the most important element in education that directs youth towards multicultural life. The best education in shaping a humanist and pluralist youth is found in religious education because moral values can be obeyed by self-awareness and high appreciation without any element of coercion from outside, but it comes from religious beliefs. Therefore, these beliefs must be nurtured and instilled since teenagers, hence it becomes an inseparable part of the personality of teenagers to adulthood. In this context, religious education gets a burden and responsibility that is not light especially when it associated with efforts to foster youth.

Religious education conventionally functions to make children of faith and piety, and noble character, thus they can live in the midst of society with peace and happiness, without experiencing significant difficulties. In other words, religious education can help youth in building a humanist and pluralist life. Teenagers with a humanist and pluralist life basically have a broad understanding but often understood with limited understanding, which is only described as obedience in carrying out all the rules of society and the state.

A humanist and pluralist teenager is expected becomes terminology that capable of describing clearly the obsessed life forms, especially related to the context of today's life. Although it is recognized that the role of religious education has not been fully capable of carrying out its functions to build teenagers who are obedient to their religious teaching, however, it does not reduce the hope of being able to build humanist and pluralist teenagers. 


\section{METHODS}

This research was a qualitative study which a literature study whose research used the study of literature and books as the main object. This research was qualitative research, which a type of research that produces findings with descriptive data, and it not achieved using statistical (quantitative) procedures. This research used a descriptive analysis method that provides description clearly, objective, systematic, analytical, and critical explanations and descriptions of the study of science that is integrated with Hindu religious education through the studies of the $V e d a$ scriptures interpreted by the integrative method. The approach of this research was carried out by gathering reading materials needed and relevant to the research theme. After collecting the reading materials, the next step was to clarify and describe the reading material.

\section{RESULTS AND DISCUSSIONS}

\section{The Role of Hindu Religious Education}

Education is a human activity and effort to improve his personality by fostering his personal potentials, namely spiritual (mind, intention, taste, creativity, and conscience) and physical (five senses and skills). Education is an effort to help consciously and deliberately given by adults (responsible) to minors towards the perfect development. It is manifested in their behavior, hence they will become responsible and moral human beings. Religious education has an important role in shaping responsible and moral human beings as mentioned above. Religious education has a mission to build a whole society and has character values, and faith and devotion. Religious education is intended to shape adolescents into human beings who have faith and devoted to God Almighty, also have good character, and increase spiritual potential. Regarding the understanding of Hindu religious education in the Decisions Association of the Unity Interpretation Seminar on Aspects of Hindu Religion I-XIV, can be explained as follows:

a. Hindu religious education outside of school is an effort to foster soul growth with the teachings of Hinduism itself as the subject matter.

b. Hindu religious education at school is an effort to foster the growth of the students' body and soul in accordance with the teachings of Hinduism (PHDI, 1988: 23-24).

According to Titib (2011), "Hindu religious education is an effort that planned and carried out continuously in order to develop the ability of students to strengthen their faith and devotion to God Almighty, have a noble character, and increase spiritual potential based on the teachings of Hinduism". Meanwhile, according to Wiana (2010), Hindu religious education is "organizing education by instilling Hindu teachings as the main source in an educational process". Based on the explanation above, it can be said that Hindu religious education is a conscious and planned effort, preparing students to get to know, understand, appreciate, to believe, as well as to devote and have a noble character in practicing Hindu teachings oriented from sruti, smerti, sila, acara, and atmanastusti.

\section{Youths Development}

Adolescence is one of the stages in human life, which often described as the most beautiful and unforgettable period because it is full of excitement and challenges. However, according to Kusuma (2010), "adolescence is synonymous with rebellion, in psychological terms itself is often referred to as a period of storm and stress, because of many shocks and changes that are quite radical from the previous period".

Meanwhile, according to Santrock (2003), "youth defined as the development of transition period between childhood and adulthood which includes biological, cognitive, and social-emotional changes." Adolescence begins around the age of 10 to 13 years and ends between the ages of 18 to 22 years. Biological, cognitive, and socialemotional changes that occur starting from the development of the sexual function, abstract thought processes to independence ". In the 
world of law, the concept of adolescents is unknown in some applicable laws. Indonesian law only recognizes children and adults, although there are various restrictions given. For example, civil law provides a limit of 21 years or less as long as someone has been married to declare himself as an adult. Criminal law gives a limit of 18 years or less as long as someone has been married as an adult age limit. UU No. 23 of 2002 concerning child protection limits the child's age is before 18 years. Whereas, UU No. 1 of 1974 concerning marriage allows the age of 16 years to get married and considered an adult.

Apart from these age restrictions, adolescence is a transition period from childhood to adulthood in all aspects, both biological, psychological, and social. This transition period is difficult for adolescents, where the change process in the body is ongoing. There are biological changes including hormonal changes, especially reproductive hormones. There are psychological changes that influenced by the association in the environment. These changes make teenage life becomes difficult and vulnerable.

\section{The Function of Hindu Religious Education for Youths}

Hindu religious education is the application of sacred teachings revealed by God which contains instructions about good deeds and should be carried out by Hindus, namely by avoiding despicable acts and keep away from actions that violate religious norms hence it can achieve perfection of physical and spiritual life. Hindu religious education for youths functions as a system that contains certain norms. This is in line with the opinion of Jalaluddin (2003), generally, norms become a frame of reference in behaving to be in line with their religious beliefs. In general, the function of religion for humans, namely:

a. Educative function. Humans entrust the educative function to religion which includes the task of teaching and guidance. b. Rescue function. Every human being wants salvation either in the present life or after death. For its assurances, they find in religion because religion teaches and provides unique ways to achieve happiness.

c. Social supervisors function. Religion is responsible for the existence of moral norms applied in society. Religion selects the existing moral principles and confirms the good and rejects the bad to be left as a prohibition or taboo.

d. The function fostering brotherhood. Through religion, peace on earth that coveted by every human being. The desire to unite not only with fellow religious people but also with other religious groups, which developing these days.

e. Transformative function. Changing the life forms of the old society into new life forms. It means that replacing old values by instilling new values (Hendropuspito, 1990).

Specifically, Hindu religious education is influential as motivation in encouraging individuals to carry out an activity, because action carried out with the background of religious beliefs are considered to have holiness element, as well as obedience. This linkage will influence youths to do something, while religion as an ethical value because in carrying out an action, someone will be bound to the provisions between which one is allowed and not according to his religious teaching.

\section{The Development of Hindu Religious Education Roles}

The development of Hindu religious education in Indonesia, especially in Bali, can be said to not yet fulfill the expectations of Hindus. This is due to the absence of Hindu educational institutions from elementary to secondary school level based on Hinduism, thus Hindu Religious Education in the formal educational institutions is still limited, which 
can only be allocated 2 (two) hours of study per week. In addition, there is no Hindu religious teaching outside of school hours which sustainable providing a deepening of Hindu religious education.

According to Widyastana (2002), Hindubased schools are schools that not only provide formal lessons in accordance with the curriculum set by the government, in religious studies only give Hindu lessons to all students, adding extracurricular lessons/ activities to increase their knowledge and beliefs to God and able to apply Hindu values in real life.

Nowadays development, Hindu religious education seems to be only teachers' responsibility in schools, even though the inculcation of religious values is very difficult and requires sustainability. Thus, joint responsibility between teachers in schools and society especially parents is required. The reality of the non-role of Hindu education in Indonesia is justified by Wiana (2000). According to Wiana, in the application of Hindu teaching values especially in Bali, there has been a shift from the actual basic concept of Hinduism. This shift happened because in a quite long time Hindus in Indonesia did not receive systematic and sustainable education and religious guidance. The training that has been carried out all this time is too traditional and only limited to ritual aspects. As a result, there are Hindu religious practices that deviate from Veda values. The implementation of Hindu religious education in Bali is more emphasis on ritual aspects (ceremonies) and has not been accompanied by efforts to provide an understanding of the divinity values in the Veda.

Thus it can be concluded that the learning of Hinduism is a series of teaching and learning activities that include a process of interaction between educators and students in a planned manner to instill the values of Hinduism education and Hindu values as well as from the learning of Hinduism that can foster the trust of students used as a guideline of life in developing noble attitudes and characteristics based on the teachings of
Hinduism (Sudarsana, Pertiwi, Selasih, \& Yuliani, 2019).

The development of Hindu religious education quality sees the explanation of UU No. 20 of 2003, it should not be fully the responsibility of the government but also a society in general. Realizing this objective condition, Hindu religious education as a national education subsystem directly or indirectly needs to increase its role, with the hope that the presence of Hindu religious education will later become more strategic in participating in developing Indonesian society, especially humanist and pluralist societies.

\section{The Substance of Hindu Religious Education}

Without ignoring the meaning of the substance of Hindu religious education for all this time which is more partial and cognitive, then the substance of Hindu religious education needs to be increased or formulated as comprehensively as possible by developing materials sourced from the humanist and pluralist Veda. Quoted from Titib (2006), Veda mantras can be described as follows:

a. The ideal nation respects humanity Gods, You are the protectors of the whole world. May You provide such an ideal nation to us that can feed the whole world (Yajurveda X.4)

b. Loving everyone and be loved by everyone

Dear God Almighty, may we be loved by Gods and national leaders. May we be loved by everyone, anyone who cares about (understands) us, whether an entrepreneur or a worker (Atharvaveda XIX. 62.1)

c. Feel the unity with all humanity

When an intelligent person maintains unity with the whole world that lives and feels unity with him, then all attachments and disasters disappear (Yajurveda XL.7).

d. Hopefully, we have harmony with everyone 
May we have harmony with familiar people and strangers too (Atharvaveda VII.54.1).

While the perspective of Hinduism as quoted from Titib (2006) about pluralism is the foundation or basis of true religious harmony, as mandated in the following Veda mantras.

a. Respect the religious pluralism (differences)/beliefs and culture, also realizing prosperity together.

Give appreciation to your people who use various regional languages and adhere to different beliefs (religions). Appreciate those who live together on this motherland. The earth that gives balance like a cow giving its milk to mankind. Thus the motherland gives abundant happiness to human beings (Atharvaveda XII.1.45).

b. Actualize the unity to achieve common goals (peace, prosperity, and happiness)

I unite the mind, and your steps to bring harmony between you. I guide those who misbehave to the right path (Atharvaveda III. 8.5).

Mankind! Be united, and get along well as if Gods were joined. I have given you the same thing, therefore create unity among you (Atharvaveda III.30.4).

c. Actualize a harmonious and dialogical life.

Mankind! Live in harmony. Be united, and work together. Speak in one language, and make decisions with one mind. Like the saints in the past who have carried out their obligations, you should not be shaken in carrying out your obligations (Rigveda X.191.2)

d. Actualize a democratic life by deliberating and fostering mutual understanding.

Mankind! Think together. Deliberate together. Unite your heart and mind with others. I grant the same mind and facilities for harmony in your life (Rigveda X.191.3).

Mankind! Have the same attention. Foster mutual understanding between you. Thus you can realize harmony and unity.

e. Developing a sincere heart and true friendship (Rigg. X.191.4).

Mankind I give you the sincerity, the same mentality, friendship without hatred, just as the mother cow loves her newborn, so you should love your neighbor (Atharvaveda III.30.1).

f. Developing true harmony, both to familiar people and strangers.

It should be harmonious with intimacy between you, as well as familiar people and strangers. Hopefully, god Asvina grains His grace on harmony between people (Atharvaveda VII.52.1).

Efforts to internalize the value of Hindu religious education in primary schools are needed in forming students of noble character. Internalization of the value of Hindu religious education is a process of incorporating the value of Hindu religious education which is entirely related to how to transfer religion based on Hinduism. Internalization of the value of Hindu religious education is done through a thorough understanding and continued in the awareness of Hinduism and the discovery of the possibility to realize it in real life. Children's character education has a higher meaning than general education because it is not only related to the problem of right and wrong, but how to plant habits about a variety of good behaviors in life, so students have high awareness and understanding, as well as caring and commitment to apply virtues in life daily (Murtini, Wardhani, Sugita, Sudarsana, \& Putri, 2019).

\section{CONCLUSION}

Religious education is an education that helps human development, especially in the development of ethics and morals. Thus, the role of Hindu religious education must be increased by providing a sufficient portion of the education system. It is expected that later 
through Hindu religious education can improve moral ethics in order to maintain national harmony, mutual respect between adherents of different religions. Mutual acceptance, respect for values, culture, and different beliefs will not automatically develop on their own. This attitude must be trained and educated to adolescents in the national education system. A teacher is not only required to master and be able to professionally teach subjects, more than that, a teacher must also be able to instill humanist and pluralist values for the achievement of an Indonesian nation that values multicultural.

\section{REFERENCES}

Hendropuspito, D. (1990). Sosiologi Agama. Yogyakarta: Kanisius.

Jalaluddin. (2003). Psikologi Agama. Jakarta: PT. Raja Grafindo Persada.

Kittelmann Flensner, K. (2015). Religious education in contemporary pluralistic Sweden. Doctoral dissertation in Humanities with specialization in Educational Science, defended 11 December 2015 at the Department of Literature, History of Ideas, and Religion, University of Gothenburg.

Kusuma, R. IG. (2010). Perkembangan Kognitif Pada Remaja dalam Tumbuh Kembang Remaja dan Permasalahannya. Jakarta: CV. Sagung Seto.

Murtini, P., Wardhani, N. K. S. K., Sugita, I. W., Sudarsana, I. K., \& Putri, I. D. A. H. (2019). Internalisasi Nilai Pendidikan Agama Hindu Dalam Membentuk Siswa Berkarakter Mulia.
Jurnal Penelitian Agama Hindu, 3(2), 175-182.

Santrock, J. W. (2003) Adolescence, Perkembangan Remaja, Edisi ke-6. Terjemahan oleh Shinto B. Adelar \& Sherly Saragih. Jakarta: Penerbit Erlangga.

Sudarsana, I. K., Pertiwi, N. G. A. A. R., Selasih, N. N., \& Yuliani, N. M. (2019, March). Application of technology in learning the religion of Hindu as an educational efforts to improve the creativity of students. In Journal of Physics: Conference Series (Vol. 1175, No. 1, p. 012164). IOP Publishing.

Tilaar, H.A.R. (1999). Pendidikan, Kebudayaan, dan Masyarakat Madani Indonesia, Strategi Reformasi Pendidikan Nasional, Remaja Rosdakarya, Bandung.

Tilaar, H.A.R. (2002). Pendidikan Kebudayaan, dan Masyarakat Madani Indonesia, Bandung: PT Remaja Rosda Karya.

Titib, I M. (2006). Teologi Hindu: Humanis, Pluralis, dan Dialogis. Dalam makalah Seminar Nasional "Agama dalam Kebudayaan Post Modernisme", Diselenggarakan oleh Institut Hindu Dharma Negeri Denpasar.

Wiana, I G. K., (2000). Penerapan Ajaran Weda di Bali, Majalah Hindu Raditya, hal 26.

Widyastana, P.A. (2002). Yadnya Pengetahuan, Menyelamatkan Generasi, Majalah Hindu Raditya, April 2003, hal 21 